\title{
Tanggung Jawab Sosial Perusahaan dalam Bisnis Islam
}

\author{
Corporate social responsibility in Islamic business
}

\section{Yuni Mayanti}

Program Studi Magister Ekonomi Islam, UIN Sunan Gunung Djati Bandung

Email: mayantiyuni@gmail.com

\section{Rani Putri Kusuma Dewi}

Program Studi Magister Ekonomi Islam, UIN Sunan Gunung Djati Bandung

Email: putrikusumadewirani@gmail.com

\begin{abstract}
This paper discusses corporate social responsibility in Islamic business or commonly known as CSR. The writing of this paper uses a qualitative descriptive method with a literature study approach by taking references from reliable sources and books and then the authors develop. This paper finds that corporate social responsibility in Islamic business has different principles from conventional business even though both have the same goals. Thus, it is deemed necessary to continue to carry out deeper studies in order to find out the company's responsibility in doing Islamic business which is very applicable in a company and can assist the company in improving the company's performance and optimal growth.
\end{abstract}

Keywords: Responsibility, Corporate, CSR, Business, Islam.

\section{Pendahuluan}

Bisnis adalah serangkaian usaha yang dilakukan satu orang atau kelompok dengan menawarkan barang dan jasa untuk mendapatkan keuntungan atau laba (Wijoyo et al., 2021, p. 1). Perusahaan harus memiliki tingkat profitabilitas yang memadai, sebab laba merupakan fondasi bagi perusahaan untuk dapat berkembang dan mempertahankan eksistensinya (Darmawati, 2014, p. 130). Perhatian Islam terhadap keuntungan bisnis tidak mengabaikan aspek-aspek moral dalam mencapai keuntungan tersebut (Sukananda, 2019, p. 9). Bisnis dalam Islam berbeda dengan bisnis konvensional. Bisnis Islam adalah suatu usaha tidak hanya untuk mendapatkan keuntungan saja tetapi harus berlandaskan hukum syariah. Bisnis Islam yang dikendalikan oleh hukum syari'ah cukup jauh berbeda dengan bisnis konvensional, dalam hal cara untuk mendapatkan kekayaan dan bagaimana menggunakannya (Huda, 2016, p. 172). Islam mengajarkan untuk berbisnis dengan tidak merugikan sebelah pihak dan bisa saling menguntungkan. Dalam bisnis Islam diajarkan bagaimana melakukan kegiatan usaha yang memiliki nilai-nilai Islam yang sesuai dengan hukum syariah yang disebut sebagai Etika bisnis Islam.

Etika bisnis Islam adalah seperangkat prinsip dan norma yang berbasiskan Al-Quran dan AlHadist yang harus dijadikan pedoman oleh semua pelaku usaha dalam aktivitas bisnis baik bisnis skala besar dan skala kecil (Hulaimi et al., 2017, p. 6). Dalam melakukan bisnis, tidak terlepas dari peran manusia dalam berinteraksi karena manusia membutuhkan hubungan dengan manusia lainnya dalam berinteraksi apapun salah satunya interaksi bisnis. Namun interaksi bisnis dalam Islam, adanya prinsip dan norma yang harus diterapkan oleh umat muslim dalam melakukan kegiatan bisnis agar kegiatan yang dilakukan mendapatkan pahala dan berkah.

Seiring berkembangnya suatu perusahaan atau bisnis yang dilakukan maka semakin banyaknya persoalan yang dihadapi salah satunya adalah adanya batasan dalam ruang gerak 
bisnisnya seperti adanya permasalahan terhadap lingkungan dalam operasi bisnisnya yang mengakibatkan adanya ketidaknyamanan terhadap masyarakat sehingga pelaku usaha perlu memiliki kedekatan hubungan dengan publik demi keberlangsungan bisnisnya maka diperlukan adanya kegiatan CSR (Corporate Social Responsibility) agar perusahaan memiliki tanggung jawab sosial. Untuk itulah CSR diperlukan agar dapat membangun nama baik perusahaan tersebut.

CSR adalah tanggung jawab sebuah organisasi terhadap dampak-dampak dari keputusan dan kegiatan-kegiatannya pada masyarakat dan lingkungan yang diwujudkan dalam bentuk perilaku transparan dan etis yang sejalan degan pembangunan berkelanjutan dan kesejahteraan masyarakat, mempertimbangkan harapan pemangku kepentingan, sejalan dengan hukum yang ditetapkan dan norma-norma perilaku Internasional, serta terintergrasi dengan organisasi secara menyeluruh (Rahmat, 2017, pp. 13-14).

Tanggung Jawab Sosial Perusahaan (CSR) hadir sebagai isu penting dalam dunia usaha atau berbisnis dengan tujuan agar hubungan antara perusahaan dan masyarakat menjadi baik dan untuk menghindari konflik yang tidak diinginkan di masa depan yang menyangkut nama dan reputasi perusahaan. Adapun Tanggung Jawab Sosial Perusahaan (CSR) dalam Islam berbeda halnya dengan CSR konvesional.

Dalam CSR konvensional dibahas mengenai tujuan perusahaan dalam mempertahankan bisnis untuk jangka panjang dengan memperhatikan kondisi lingkungan dan sosial. Tujuan ini adalah salah satu tujuan yang dilakukan juga CSR dalam Islam dimana CSR dalam Islam juga memperhatikan kondisi lingkungan sekitar dan sosial namun CSR dalam Islam tidak hanya untuk tujuan duniawi saja agar perusahaan terus bertahan tetapi bertujuan untuk akhirat juga dimana hal tersebut merupakan salah satu kewajiban dan perintah dari Allah SWT agar kita meperhatikan lingkungan dan sesama. Adapun dalam Islam mewajibkan adanya niat yang tulus dan ikhlas untuk membantu dan menolong sesama. Berdasarkan paparan diatas maka penulis ingin mengetahui lebih dalam mengenai tanggung jawab sosial perusahaan dalam bisnis Islam.

\section{Kajian Pustaka}

Bisnis yaitu suatu organisasi yang menjual barang atau layanan pada customer atau bisnis lainnya, untuk memperoleh laba. Secara historis kata bisnis berasal dari bahasa Inggris business, dari kata dasar busy yang bermakna "sibuk" dalam konteks individu, komunitas maupun masyarakat. Dalam artian, sibuk mengerjakan kesibukan serta pekerjaan yang mendatangkan keuntungan. Secara etimologi, bisnis bermakna keadaan dimana seseorang atau sekumpulan orang sibuk melakukan pekerjaan yang membuahkan keuntungan. Kata "bisnis" sendiri mempunya tiga penggunaan, tergantung skupnya, penggunaan singular kata bisnis bisa mengacu pada badan usaha, yakni kesatuan yuridis (hukum), teknis, serta ekonomis yang mempunyai tujuan mencari laba atau keuntungan (Kamaluddin \& Rapanna, 2017, pp. 5-6).

Terdapat dua pengertian pokok mengenai bisnis, pertama, bisnis merupakan kegiatankegiatan, dan kedua, bisnis merupakan sebuah perusahaan (Umar, 2003, p. 3).

Bisnis Islami adalah ikhtiar yang bisa dijalankan dengan menanamkan niat dan tekad kuat dalam merubah sesuatu yang asalnya tidak bisa menghasilkan sesuatu yang berharga menjadi barang yang bernilai dan mendatangkan kesuksesan bisa dijalankan dengan baik dan benar (halalan thoyyibah). Bisnis syariah adalah bisnis yang dijalankan dengan memperhatikan segala bentuk larangan-larangan yang diharamkan syariah Islam dan menjalankan sesuai dengan prinsip syariah dengan mengharapkan keberkahan dan keridhoan kepada Allah sebagai pencipta alam semesta (Latifah, 2020, p. 2).

Bisnis Islami dapat diartikan sebagai serangkaian aktivitas bisnis dalam berbagai bentuknya yang tidak dibatasi jumlah (kuantitas) kepemilikan hartanya (barang/jasa) termasuk profitnya, 
namun dibatasi dalam cara perolehan dan pendayagunaan hartanya (ada aturan halal dan haram) (Yusanto, 2002, p. 18).

Tanggung jawab sosial perusahaan atau Corporate Social Responsibility (CSR) adalah upaya sungguh-sungguh dari entitas bisnis untuk meminimalkan dampak negatif dan memaksimalkan dampak positif operasinya terhadap seluruh pemangku kepentingan dalam ranah ekonomi, sosial, dan lingkungan agar mencapai tujuan pembangunan berkelanjutan (Rachman et al., 2011, p. 15).

Corporate Social Responsibility (CSR) merupakan sebuah gagasan yang menjadikan perusahaan tidak lagi dihadapkan pada tanggung jawab yang berpijak pada single bottom line dalam bentuk ekonomi atau nilai perusahaan saja, tetapi juga berpijak pada triple bottom line yaitu tanggung jawab terhadap masalah sosial dan lingkungan (Nurlaela Wati, 2019, p. 1).

\section{Metode Penelitian}

Untuk mendapatkan informasi yang valid, reliable dan obyektif maka penulis menyusun sebuah metode penelitian. Metode kualitatif menjadi metode penelitian yang digunakan peneliti dengan pendekatan studi literature yang mana diambil dari sumber terpercaya, buku-buku sebagai referensi kemudian di analisis oleh penulis dan contoh implementasi nya pada saat ini.

\section{Hasil dan Pembahasan}

Istilah CSR singkatan dari corporate social responsibility sendiri diperkenalkan pertama kali dalam tulisan Social Responsibility of the Bussinessman tahun 1953 yang digagas Howard Rothmann Browen. CSR adalah sebuah pendekatan dimana perusahaan mengintegrasikan kepedulian sosial dalam operasi bisnis mereka (Nurlaela Wati, 2019, p. 11). Dalam menjalankan suatu bisnis, perusahaan tidak terlepas dari pemangku kepentingan yaitu pemangku kepentingan Terdapat dua pemangku kepentingan dalam menjalankan suatu bisnis yaitu pemangku kepentingan internal dan eksternal. Adapun pemangku kepentingan internal yaitu para pemegang saham dan para pekerja sedangkan pemangku kepentingan eksternal diantaranya pemerintah, konsumen, suplier, lembaga swadaya masyarakat (LSM), komunitas dan masyarakat. Dalam Perusahaan atau organisasi memiliki keterlibatan dengan berbagai pihak yang ada di dalam organisasi maupun di luar organisasi (Trihastuti, 2021, p. 8). TJSL atau CSR muncul karena adanya kesadaran mengenai pertumbuhan perusahaan dalam jangka panjang dan tidak hanya fokus pada keuntungan saja.

Tanggung jawab sosial perusahaan atau yang lebih dikenal dengan CSR adalah suatu konsep yang berkembang pesat sejak tahun 1980. Konsep tersebut muncul karena reaksi dari organisasi masyarakat sipil untuk menumbuhkan perilaku etis atau beretika yang berlaku untuk intern ataupun ekstern perusahaan yaitu stakeholder, masyarakat sekitar perusahaan dan organisasi atau komunitas yang mempengaruhi perusahaan beroperasi.

Dalam pengertian lain CSR adalah gagasan dengan mengacu pada triple bottom line bukan single bottom line. Single bottom line adalah acuan perusahaan dengan memperhatikan kondisi keuangan saja tetapi tidak memperhatikan kondisi lingkungan dan sosial sedangkan triple bottom lines adalah aspek ekonomi nilai perusahaan yang berpijak pada finansial, sosial dan lingkungan. 


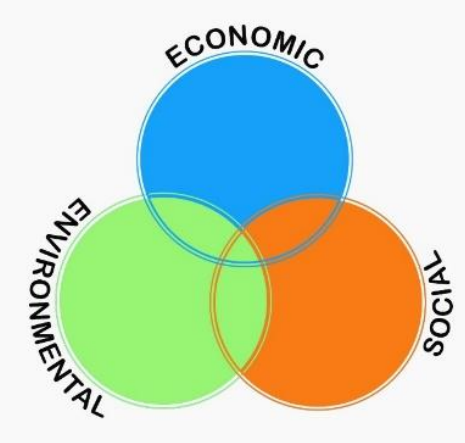

Gambar 1. Triple bottom lines

Gambar diatas merupakan gambaran mengenai triple bottom line yang menjadi pijakan CSR dimana perusahaan tidak hanya bertanggung jawab terhadap masalah perusahaannya nya saja tetapi pada masalah sosial dan lingkungan sekitar perusahaannya juga. Triple bottom line tersebut dikenal dengan 3P (Profit, People dan Planet). Ketiga elemen tersebut yaitu keuntungan, masyarakat (kepentingan pembangunan manusia) dan lingkungan yang menjadi konsep pembangunan berkelanjutan.

Dalam bisnis Islam dianjurkan adanya keseimbangan antara aktivitas bisnis dan nilai-nilai bisnis berdasarkan ajaran-ajaran Islam. Sebagaimana dalam Al-Quran dibahas pula mengenai Tanggung jawab sosial yang mana moral seorang pengusaha dalam melakukan aktivitas bisnis berpengaruh terhadap kesuksesan suatu bisnis yang terdapat dalam surat al-Israa' ayat 35: "Dan sempurnakanlah takaran apabila kamu menakar, dan timbanglah dengan neraca yang benar. Itulah yang lebih utama (bagimu) dan lebih baik akibatnya".

Adapun Al-Quran membahas untuk menjaga dan melestarikan lingkungan dalam surat AlBawarah ayat 205: "Dan apabila ia berpaling (dari kamu), ia berjalan di bumi untuk mengadakan kerusakan padanya, dan merusak tanam-tanaman dan binatang ternak, dan Allah tidak menyukai kebinasaan".

Sedangkan kegiatan CSR dalam Al-Quran diterangkan dalam surat An-Nisa ayat 36 dan 37 :

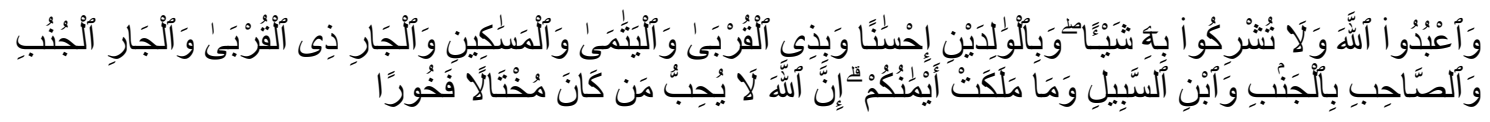

"Sembahlah Allah dan janganlah kamu mempersekutukan-Nya dengan sesuatupun. Dan berbuat baiklah kepada dua orang ibu-bapa, karib-kerabat, anak-anak yatim, orang-orang miskin, tetangga yang dekat dan tetangga yang jauh, dan teman sejawat, ibnu sabil dan hamba sahayamu. Sesungguhnya Allah tidak menyukai orang-orang yang sombong dan membangga-banggakan diri”.

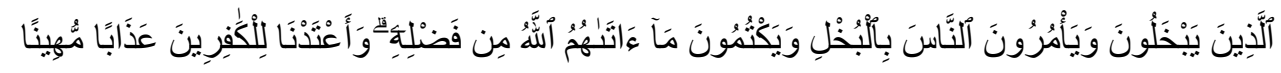

"(yaitu) orang-orang yang kikir, dan menyuruh orang lain berbuat kikir, dan menyembunyikan karunia Allah yang telah diberikan-Nya kepada mereka. Dan Kami telah menyediakan untuk orangorang kafir siksa yang menghinakan.”.

Salah satu konsep perusahaan dalam jangka panjang dan dapat mempertahankan perusahaan tersebut dengan memiliki tanggung jawab terhadap dampak yang ditimbulkan perusahaan disebut sebagai CSR. Dampak yang dimaksud misalnya polusi, limbah, keamanan produk dan tenaga kerja. 
TJSL tidak hanya terbatas pada pemberian bantuan sosial terhadap masyarakat saja tetapi pada karyawannya juga dengan tidak melakukan diskriminatif.

Salah satu contoh implementasi tanggung jawab sosial perusahaan terhadap stakeholder eksternal misalnya melakukan perbaikan lingkungan di sekitar perusahaan yang terdampak dalam operasional perusahaan misalnya limbah yang harus diminimalisir. Sedangkan contoh implementasi Tanggung jawab sosial perusahaan terhadap stakeholder internal yaitu memberikan persamaan hak dan kewajiban terhadap seluruh karyawan misalnya memberikan fasilitas gaji yang sesuai dengan UMR, memberikan waktu untuk beristirahat dan memberikan fasilitas tempat untuk beribadah.

Dalam bisnis Islam, konteks tanggung jawab sosial perusahaan adalah bagaimana konsep tersebut didasarkan pada beberapa sifat terpuji Rasulullah dalam berbisnis dimana Rasulullah menjalankan bisnis atau berdagang dengan sifat Shidiq, Istiqamah, Fathanah, Amanah dan Tabligh atau bisa disingkat SIFAT. Sebuah perusahaan harus memiliki budaya kerja yang sesuai syariah Islam dengan ciri-ciri yaitu adanya kejujuran (shiddiq), konsisten (istiqamah), pandai (fathonah), bertanggungjawab (amanah), dan mengajak (tabligh) (Amrin, 2011, pp. 13-15).

a. Shiddiq berarti jujur. Artinya dalam menjalani konsep CSR dalam bisnis Islam dituntut untuk memiliki kejujuran dalam segala tindakan dan perbuatan. Perusahaan perlu transparan, misalnya perusahaan harus jujur terhadap konsumen mengenai kekurangan dan kelemahan produk.

b. Istiqamah berarti konsisten. Artinya perusahaan harus konsisten dalam menjalan bisnis dengan baik. Perusahaan perlu menepati janji dan tepat waktu.

c. Fathonah berarti mengerti. Artinya perusahaan perlu memahami dan menghayati mengenai kewajiban dan tugas-tugas perusahaan. Perusahaan harus memberikan pelayanan secara optimal, selalu berusaha meningkatkan dan memperbaiki kualitas.

d. Amanah berarti tanggung jawab. Artinya perusahaan harus bertanggung jawab dalam segala tugas perusahaan dibarengi dengan sifat ihsan misalnya melakukan konsep tanggung jawab sosial perusahaan.

e. Tabligh berarti mengajak dalam kebaikan. Misalnya perusahaan memberikan penyampaian sesuatu dengan bijak dan ada hikmahnya dan sabar sehingga dapat meningkatkan hubungan kemanusiaan yang solid.

Dalam perspektif Islam, Pencapaian keuntungan tidak boleh mengabaikan aspek-aspek moral. Sehingga perusahaan harus memiliki kesadaran mengenai etika dan moral karena jika pelaku usaha tidak memiliki moral dan etika yang baik dalam berbisnis maka akan menjadi ancaman dalam hubungan sosial, konsumen dan perusahaanya sendiri. Komitmen untuk menjaga kontrak sosial dengan tulus merupakan salah satu tanda adanya norma-norma Islam di dalam operasional bisnis perusahaan tersebut.

Dalam Islam, CSR berfokus pada pembahasan etika dalam bisnis Islam sesuai dengan ajaran etika Islam. Permasalahan seperti bagaimana memproduksi sebuah barang atau jasa yang halal, etika menggunakan iklan sebagai media promosi, harga yang tidak terlalu tinggi dan tidak merugikan konsumen, pertanggungjawaban polusi akibat dampak dari produksi dan lain sebagainya adalah halhal yang dibahas dalam pelaksanaan etika. Sehingga peran pengusaha sebagai pelaku bisnis harus memperhatikan juga lingkungan sekitar dengan tidak menggunakan sumber daya alam secara berlebihan tanpa memperhatikan kepentingan masa yang akan datang (Agus Harjito, 2002, p. 124).

Tanggung jawab sosial terhadap lingkungan salah satunya faktor-faktor produksi dalam bisnis Islam :

a. Faktor Produksi Alam

Sumber daya alam yang ada di muka bumi ini diciptakan oleh Allah SWT untuk digunakan manusia dengan cara dikelola dengan benar hanya untuk tujuan beribadah kepada Allah SWT 
semata. Sumber daya tersebut termasuk bagian dari faktor produksi alam. Dalam firman Allah surat Abasa ayat 25-32 menyebutkan bahwa "Allah mencurahkan air dari langit dan membelah bumi dan menumbuhkan biji-bijian di bumi, anggur dan sayuran, pohon kurma, kebun yang lebat buahnya untuk kesenanganmu dan untuk binatang ternakmu". Dalam ayat tersebut bermakna bahwa pemanfaat sumber daya alam harus sesuai kebutuhan. Karena jika alam dieksploitasi secara berlebihan akan berdampak pada bencana alam seperti kekeringan, banjir dan lainnya sehingga penggunaan sumber daya harus dimanfaatkan dengan baik agar tidak berdampak pada kerusakan lingkungan.

\section{b. Tenaga kerja}

Dalam pemanfaatan tenaga kerja harus diperhatikan Hak Asasi Manusia (HAM) dengan membayar upah atau gaji yang sesuai atau di Indonesia diberlakukannya UMR (Upah minimum regional). Juga perusahaan perlu memperhatikan jaminan kesehatan sosial para karyawan dan berupaya untuk mensejahterakan karyawannya. Sesuai hadist bukhari mengatakan bahwa "manusia saling memberi kepada yang lainnya" dan sebuah hadist yang diungkap Ibnu Majah bahwa memberikan upah kepada karyawan sebelum keringatnya kering.

\section{c. Modal}

Modal adalah dana atau kekayaan perusahaan untuk melakukan proses produksi bisa berupa modal pribadi atau modal asing. Modal dari dikeluarkan dari pemilik perusahaan sendiri disebut modal pribadi sedangkan modal asing berarti modalnya berasal dari pihak eskternal (luar) misalnya berhutang kepada perusahaan lain baik perbankan atau non perbankan. Biasanya memiliki masalah yang panjang jika modal didapatkan dari modal asing.

\section{d. Skill dan Kemampuan}

Pelaku bisnis harus memiliki skill dan kemampuan dalam mengelola kegiatan bisnis dengan cara terampil mengatur operasional kegiatan produksi seperti pelaku bisnis perlu memberikan hak kepada tenaga kerja untuk beribadah dengan fasilitas yang memadai sehingga adanya keseimbangan dalam keimanan dan keuntungan yang ingin diraih (Agus Harjito, 2002, p. 126).

Prinsip-prinsip produksi dalam islam harus merupakan teori tentang basic need (dasar kebutuhan). Sejatinya teori dasar aktivitas produksi untuk mencukupi segala kebutuhan. Misalnya Membangun sebuah pabrik tekstil kemudian menghasilkan limbah yg mengalir. Jika limbah tersebut tercemar lantas bagaimana orang sekitarnya bisa bersuci. Sehingga produksi ini menjadi produksi yg tidak memenuhi kebutuhan manusia. Untuk itu faktor produksi ini pun menjadi penting untuk diperhatikan untuk menjaga lingkungan sekitar. Dan kegiatan produksi pun harus bernilai Islam. Dalam maqashid syariah ada prioritas dalam memenuhi kebutuhan produksi misalnya produksi minuman keras yang secara nyata dapat menghasilkan penghasilan bagi perusahaan dan pemerintah tetapi minuman keras jika dikonsumsi berlebihan akan berbahaya dan merusak manusia sehingga yang perlu didahulukan adalah menjaga akal daripada menjaga harta.

Adapun kegiatan CSR dalam Islam memiliki tujuan untuk menciptakan kebajikan yang tidak mengandung haram misalnya ada unsur riba tetapi kegiatan yang diperintahkan Allah. Fokus utama tanggung jawab sosial perusahaan dalam Islam adalah pada ketulusan hati pelaku bisnis. Sebagaimana Rasulullah SAW bersabda : "Memenuhi keperluan seorang mukmin lebih Allah cintai dari pada melakukan dua puluh kali haji dan pada setiap hajinya menginfakkan ratusan ribu dirham dan dinar".

Untuk menjaga keseimbangan kekayaan dalam pendistribusian di masyarakat maka CSR muncul sebagai upaya untuk mengurangi permasalahan sosial di masyarakat. Sebagaimana firman Allah dalam surat Al Hasyr ayat 7: "Apa saja harta rampasan (fai-i) yang diberikan Allah kepada Rasul-Nya (dari harta benda) yang berasal dari penduduk kota-kota maka adalah untuk Allah, untuk Rasul, kaum kerabat, anak-anak yatim, orang-orang miskin dan orang-orang yang dalam perjalanan, 
supaya harta itu jangan beredar di antara orang-orang kaya saja di antara kamu. Apa yang diberikan Rasul kepadamu, maka terimalah. Dan apa yang dilarangnya bagimu, maka tinggalkanlah. Dan bertakwalah kepada Allah. Sesungguhnya Allah amat keras hukumannya”.

Adapun mengenai Zakat, Allah telah perintahkan untuk diberikan kepada 8 asnaf yang dijelaskan dalam surat At Taubah ayat 60: "Sesungguhnya zakat-zakat itu, hanyalah untuk orangorang fakir, orang-orang miskin, pengurus-pengurus zakat, para mu'allaf yang dibujuk hatinya, untuk (memerdekakan) budak, orang-orang yang berhutang, untuk jalan Allah dan untuk mereka yang sedang dalam perjalanan, sebagai suatu ketetapan yang diwajibkan Allah, dan Allah Maha Mengetahui lagi Maha Bijaksana”.

Dan Islam pun menganjurkan untuk bersedekah sebagaimana yang dibahas juga dalam AlQuran surat An Nisa ayat 114: "Tidak ada kebaikan pada kebanyakan bisikan-bisikan mereka, kecuali bisikan-bisikan dari orang yang menyuruh (manusia) memberi sedekah, atau berbuat ma'ruf, atau mengadakan perdamaian di antara manusia. Dan barangsiapa yang berbuat demikian karena mencari keridhaan Allah, maka kelak Kami memberi kepadanya pahala yang besar".

Tujuan CSR dalam Islam adalah menciptakan kebajikan yang tidak mengandung haram, menjaga keseimbangan distribusi kekayaan di masyarakat, mencapai keuntungan duniawi dan ukhrowi. Kegiatan tanggung jawab sosial perusahaan dalam bisnis Islam diantaranya Pendistribusian Zakat, Infaq, Sedekah, Wakaf dan lain sebagainya. Mengenai wakaf tercantum dalam Surat Ali Imran ayat 92 : "Kamu sekali-kali tidak sampai kepada kebajikan (yang sempurna), sebelum kamu menafkahkan sehahagian harta yang kamu cintai. Dan apa saja yang kamu nafkahkan maka sesungguhnya Allah mengetahuinya".

Salah satu contoh tanggung jawab dalam wakaf yaitu perusahaan multinasional di malaysia yang bernama Johor corporation (Jcorp) yang telah mengetengahkan sebuah konsep wakaf perusahaan sebagai suatu cara pelibatan Jcorp dalam usaha-usaha untuk mencapai pembangunan yang berkeadilan dan berkelanjutan. Jcorp mempunyai lebih dari 250 anak perusahaan dengan sembilan diantaranya terdaftar di Bursa Malaysia dan London. Wakaf perusahaan mulai diterapkan pada tahun 2006 dan Jcorp mewakafkan saham miliknya dalam tiga anak perusahaan yang terdaftar di bursa dengan nilai aset bersih berjumlah RM200 juta. Untuk tujuan pengelolaannya Jcorp menyerahkan pengendalian dana wakaf itu kepada satu perusahaan pengelola dana wakaf yaitu Grup Wakaf An-Nur (Santoso, 2011, p. 7).

Dalam praktik tanggung jawab sosial perusahaan terhadap konsumsi diantaranya :

a. Kepuasan Konsumen

Misalnya konsumen puas dengan layanan perusahaan dalam menghadapi berbagai keluhan dan permasalahan barang yang diterima. Misalnya barang sesuai dengan apa yang dibeli, jika tidak sesuai maka perusahaan wajib membantu dan memeriksa sampai tuntas tidak dibiarkan begitu saja. After sales service nya yang harus ditingkatkan.

b. Penetapan harga yang sesuai

Harga tidak terlalu mahal dan mengambil keuntungan tidak terlalu tinggi. Imam Ghazali mengatakan bahwa pengambilan keuntungan yang wajar berkisar lima persen sampai sepuluh persen adapun Imam Ghazali menambahkan bahwa keuntungan di akhirat harus lebih diutamakan dibandingkan keuntungan duniawi semata.

c. Jaminan barang

Penggunaan material yang ramah lingkungan dan barang yang dibeli merupakan barang yang halal dan terbebas dari unsur haramnya. Atau di Indonesia misalnya harus ada sertifikat halalnya dari MUI.

CSR dalam perspektif Islam lebih menekankan kepada etika bisnis Islam dimana sebuah 
perusahaan beroperasional dengan jujur dan transparan dan serta memberikan pelayanan yang unggul untuk setiap produknya. Misalnya perusahaan memiliki jaminan dalam memberikan pelayanan dengan optimal serta menjauhi praktik korupsi. Pelaksanaan CSR dalam perusahaan bisa dikategorikan ke dalam ibadah jika dilakukan dengan niat yang ikhlas dan tulus. Artinya bahwa pelaksanaan CSR bukan merupakan sebuah ibadah yang diwajibkan namun jika tujuan dan niatnya ikhlas dan tulus untuk membantu sesama dan berharap adanya ridha Allah SWT, maka pelaku bisnis tersebut akan mendapat pahala seperti melakukan ibadah. Sehingga CSR tidak hanya memberikan keuntungan kepada perusahaan agar masyarakat lebih dekat tetapi pengelolanya pun mendapat pahala dari Allah SWT.

Dalam kenyataanya, masih banyak pelaku bisnis yang melaksanakan CSR karena ingin mencapai keuntungan duniawi saja tanpa mengharap ridha Allah SWT, maka kegiatan CSR tersebut tidak akan bernilai ibadah. Sehingga pelaku bisnis menjadi rugi karena perusahaan tersebut menjadi jauh dari nilai nilai Islam yang tidak bertujuan untuk keuntungan di akhirat.

Menurut Asyraf Wajdi Dusuki dan Irwani bahwa amalan CSR jika dikaitkan dengan Maqashid syariah dapat dibagi menjadi tiga bagian yaitu kategori daruriat (essentials), kepentingan (necessary), kemewahan (embellishment) dimana tujuannya adalah untuk memberikan petunjuk bagi manajemen perusahaan untuk melaksanakan program CSR dengan pendekatan teori maqashid syariah dalam perusahaan (Santoso, 2011, p. 4).

Dalam kategori daruriat menurut Asy-Syatibi disebutkan ada 5 komponen hidup yang harus dipelihara oleh seluruh manusia yaitu hifdzul nafs (menjaga jiwa), hifdzul aql (menjaga akal), hifdzul maal (menjaga harta), hifdzul nasl (menjaga keturunan) dan hifdzud diin (menjaga agama). Sedangkan, Syeikh Yusuf Al-Qardhawi, seorang fuqaha kontemporer menambahkannya dengan hifdzul bi-ah (menjaga lingkungan hidup) (Abdilah, 2020, p. 30).

Mengenai persentase untuk penentuan program CSR dalam keuntungan perusahaan dapat dihitung berdasarkan sebuah hadist dari Abu Hurairah R.A dari Nabi SAW: "Beliau bersabda bahwa ketika berada di padang pasir, salah seorang mendengar suara dari awan, 'Curahkanlah air ke atas tanah Si Fulan'. Setelah itu awan tersebut mulai bergerak ke suatu arah dan menurunkan hujan lebat ke atas sebidang tanah yang keras dan berbatu. Seluruh air itu menggenang di suatu tempat lalu mengalir melalui satu saluran. Orang yang mendengar suara itu pun mengikuti aliran air itu. Air itu telah sampai ke suatu tempat di mana seseorang sedang sibuk memasukkan air itu ke tanahnya. Dia bertanya kepada orang itu,'Siapakah Anda?' Orang itu memberitahukan namanya seperti yang ia dengar dari awan tadi. Pemilik tanah itu kemudian bertanya, 'Mengapa Anda menanyakan nama saya?' Dia berkata, 'Saya mendengar suara dari awan yang daripadanya Anda mendapat air, 'curahkanlah air kepada tanah Si Fulan, dan nama Andalah yang telah saya dengar dari awan itu. Amalan apakah yang Anda lakukan di tanah ini?' Pemilik tanah berkata :'Karena Anda telah menjelaskan semuanya, saya pun terpaksa menerang-kannya. Apa pun yang saya hasilkan dari tanah ini saya bagikan ke dalam tiga bagian. Satu bagian segera saya sedekahkan di jalan Allah Swt., satu bagian saya gunakan untuk keperluan anak-isteri, dan satu bagian lagi saya gunakan untuk tanah ini'.'(Lahuri, 2013, pp. 2-3).

Hadist diatas menerangkan mengenai pembagian penghasilan dalam suatu keuntungan. Hal ini bisa di aplikasikan kepada perusahaan dalam mengelola keuntungan yang didapatkan. Dijelaskan bahwa satu bagian untuk disedekahkan artinya ada keuntungan yang harus dipisahkan untuk keperluan sedekah dimana sedekah ini bisa dikategorikan sebagai tanggung jawab sosial perusahaan dalam bisnis Islam, sedangkan satu bagian untuk keperluan anak istri bisa dimasukan ke dalam pengeluaran untuk biaya-biaya perusahaan seperti pembayaran gaji karyawan dan lainnya sedangkan satu bagian lagi untuk digunakan untuk lahan bisa dimasukan ke dalam perputaran modal kembali agar perusahaan semakin berkembang. Hal ini bisa kita hitung bahwa 33,33\% untuk modal perusahaan kembali, 33,33\% untuk pengeluaran atau biaya-biaya perusahaan dan 33,33\% untuk 
program CSR dengan bersedekah.

\section{Penutup}

Dalam Islam, CSR berfokus pada pembahasan etika dalam bisnis Islam sesuai dengan ajaran etika Islam. Komitmen untuk menjaga kontrak sosial dengan tulus merupakan salah satu tanda adanya norma-norma Islam di dalam operasional bisnis perusahaan tersebut. Adapun pencapaian keuntungan dalam bisnis Islam tidak mengabaikan aspek-aspek moral.

Terdapat dua macam pemangku kepentingan dalam menjalankan perusahaan yaitu pemangku kepentingan internal dan eksternal. Pemangku kepentingan internal yaitu para pemegang saham dan para pekerja sedangkan pemangku kepentingan eksternal diantaranya pemerintah, konsumen, suplier, lembaga swadaya masyarakat (LSM), komunitas dan masyarakat.

Dalam konteks tanggung jawab sosial perusahaan atau CSR dalam bisnis Islam adalah bagaimana konsep tersebut didasarkan pada beberapa sifat terpuji Rasulullah dalam berbisnis dimana Rasulullah menjalankan bisnis atau berdagang dengan sifat Shidiq, Istiqamah, Fathanah, Amanah dan Tabligh atau bisa disingkat SIFAT.

Niat yang baik, tulus serta ikhlas adalah fokus tujuan CSR dalam bisnis Islam untuk membantu masyarakat yang benar-benar membutuhkan, menciptakan kebajikan yang tidak mengandung haram, menjaga keseimbangan distribusi kekayaan di masyarakat, mencapai keuntungan duniawi dan ukhrowi, melaksanakan perintah Allah SWT yang digali dari Al-Quran dan Sunnah. Tanggung jawab sosial perusahaan dalam bisnis Islam pada faktor produksi diantaranya sumber daya alam, tenaga kerja, modal dan skill sedangkan dalam kegiatan pendistribusian diantaranya Zakat, Infaq, Sedekah, Wakaf dan lain sebagainya serta dalam faktor konsumsi misalnya perusahaan harus memastikan bahwa barang yang diproduksi merupakan barang yang halal sesuai syariat Islam.

Dengan demikian, CSR dalam bisnis Islam adalah tanggung jawab pelaku bisnis sebagai wakil dari perusahaan kepada Allah SWT dengan tujuan untuk memperoleh keuntungan duniawi serta keuntungan akhirat sehingga pelaksanaan CSR dapat bernilai ibadah dan mendapatkan pahala.

\section{Daftar Pustaka}

Abdilah, S. (2020). Sedekah Digital: Dari Aksi Maya Ke Nyata. Sadira Books \& BukuMu.

Agus Harjito. (2002). Etika Bisnis Dan Tanggung Jawab Sosial Perusahaan Dalam Perspektif Islam. Al-Mawarid Journal of Islamic Law, 8, 118-127.

Amrin, A. (2011). Strategi pemasaran asuransi syariah. Grasindo.

Darmawati, D. (2014). Corporate Social Responsibility dalam Perspektif Islam. Marahib, 13(2), Article 2. https://doi.org/10.21093/mj.v13i2.387

Huda, C. (2016). Model Pengelolaan Bisnis Syari'ah: Studi Kasus Lembaga Pengembangan Usaha Yayasan Badan Wakaf Sultan Agung Semarang. Walisongo: Jurnal Penelitian Sosial Keagamaan, 24, 165. https://doi.org/10.21580/ws.24.1.1140

Hulaimi, A., Sahri, S., \& Huzaini, M. (2017). Etika Bisnis Islam dan Dampaknya Terhadap Kesejahteraan Pedagang Sapi. JEBI Jurnal Ekonomi dan Bisnis Islam), 2(1), 17-32. https://doi.org/10.15548/jebi.v2i1.64

Kamaluddin, A., \& Rapanna, D. P. (2017). Administrasi Bisnis. SAH MEDIA.

Lahuri, S. bin. (2013). Corporate Social Responsibility dalam Perspektif Islam. Ijtibad: Jurnal Hukum Dan Ekonomi Islam, 7(2), Article 2. https://doi.org/10.21111/ijtihad.v7i2.85

Latifah, E. (2020). Pengantar Bisnis Islam. Penerbit CV. SARNU UNTUNG. 
Nurlaela Wati, L. (2019). Model Corporate Social Responsibility (CSR). Myria Publisher.

Rachman, N. M., Efendi, A., \& Wicaksana, E. (2011). Panduan Lengkap Perencanaan CSR. Penebar Swadaya Grup.

Rahmat, B. Z. (2017). Corporate Social Responsibility dalam Perspektif Etika Bisnis Islam. Amwaluna: Jurnal Ekonomi dan Keuangan Syariah, 1(1), 98-113. https://doi.org/10.29313/amwaluna.v1i1.2099

Santoso, B. (2011). Wakaf Perusabaan: Model CSR Islam untuk Pembangunan Berkelanjutan. Universitas Brawijaya Press.

Sukananda, S. (2019). Konsep Tanggung Jawab Sosial Perusahaan Melalui Pendekatan Filsafat Hukum Islam. Lex Renaissance, 4(2), 386-409. https://doi.org/10.20885/JLR.vol4.iss2.art11

Trihastuti, A. E. (2021). Etika Bisnis Islam. Deepublish.

Umar, H. (2003). Business an Introduction. Gramedia Pustaka Utama.

Wijoyo, H., Sunarsi, D., Cahyono, Y., \& Ariyanto, A. (2021). Pengantar Bisnis. Insan Cendekia Mandiri.

Yusanto, M. I. (2002). Menggagas bisnis Islami. Gema Insani. 